\author{
Journal of Forests \\ 2022 Vol. 9, No. 1, pp. 1-8. \\ $\operatorname{ISSN}(e):$ 2409-3807 \\ $\operatorname{ISSN}(p): 2413-8398$ \\ DOI: $10.18488 /$ jof.v9i1.2126 \\ (C) 2022 Conscientia Beam. All Rights Reserved. \\ check for
updates
}

\title{
BIOINDICATORS OF BEHAVIOR AND REGENERATION OF A CAATINGA AREA IN THE BRAZILIAN SEMI-ARID - A REVIEW
}

Cassio Ricardo
Goncalves da Costa
Marcos Gomes da
Silva $^{2}$
Carlos Antonio
Gonçalves da Costa $^{3}$
Rayane Sley Melo da
Cunha $^{4}$
Marcia Mayara
de Sousa $^{5}$
Maria Vanessa
Pires de Sousa
Anne Carolline
Maia Linhares
Sonaria de Sousa $^{7}$
Silva
Ailson de Lima
Marques
Debora Coelho de $_{\text {Moura }}{ }^{10}$

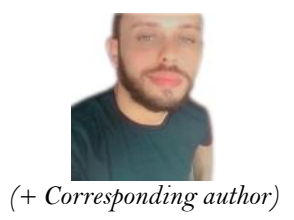

${ }_{2,3,7, s}$ Department of Soils and Rural Engineering, Federal University of Paraiba, Brazil.

${ }^{2} E m a i l:$ marcos.silva.quimico@gmail.com

${ }^{3}$ Email: carlosagronomia2007@yahoo.com.br

Email:anemaia-16@hotmail.com

${ }^{8}$ Email:sonnariasousa@gmail.com

${ }^{\circ}$ Department of Geography, Federal University of Paraiba, Brazil.

${ }^{9}$ Email:marques.ailsonl@gmail.com

${ }^{10}$ Department of Geography, Federal University of Campina Grande, Campina Grande, Brazil.

${ }^{10}$ Email:_ebygeo@hotmail.com

\begin{abstract}
Studies that allow the understanding of the nutrient cycling processes and maintenance of soil fertility in the caatinga biome are necessary to assist in the proposal of possible management forms, in view of the sustainability of this ecosystem, to provide data in an area of knowledge the quantification of glomalin can be a good indicator of changes caused by the use of the soil and, in turn, therefore, it can become a good indicator of its recovery because it is correlated with important attributes of the soil. In addition to providing data of this process for a better understanding of the soils of the country, a study on this subject will also contribute with a new database for global monitoring. Research that can follow the regeneration rate of Caatinga forests in the Semi-arid will allow the development of models relating to several variables, not currently available

for the semi-arid tropical region.
\end{abstract}

Article History

Revised: 10 November 2021 Accepted: 14 December 2021

Keywords

Forest

Global warming

Caatinga research.

Contribution/Originality: The caatinga biome has greater diversity than any biome in a semiarid climate. However, much of this biome has been deforested, causing a loss of diversity and an increase in degraded areas. The use of biological indicators sensitive to the changes that have occurred are essential to propose conservation measures and adequate management of these areas. 


\section{INTRODUCTION}

The Caatinga is the most extensive biome in the Northeast of Brazil, occupying an area of $844,453 \mathrm{~km}^{2} \mathrm{or}_{11} \%$ of the national territory [1] a biome characterized by a marked water deficit, high insolation and evapotranspiration rates, as well as reduced and variable precipitation, which ends up determining the distribution of the species and the production of biomass. According to Albuquerque and Andrade [2] the Caatinga is linked to the idea of unproductivity, and would be a smaller source of natural resources, this idea seems always related to the arid and semi-arid areas of the world. The extension of the semi-arid region, defined based on climatic criteria, is slightly superior to the area of the caatinga biome, covering 1.135 municipalities in nine NE states. The total area is $980,000 \mathrm{~km}^{2}$ with a population of 23.8 million inhabitants, numbers that define the highest population density of all the semiarid regions of the world (http://www.insa.gov.br/sigsab/basico). The agricultural establishments reach the number of 1.7 million, with a rural population of 8.6 million. Average annual temperatures range from 24 to 26 ${ }^{\circ} \mathrm{C}$, with monthly mean variation lower than $5{ }^{\circ} \mathrm{C}$ and daily variations between $5-10{ }^{\circ} \mathrm{C}$. The average relative

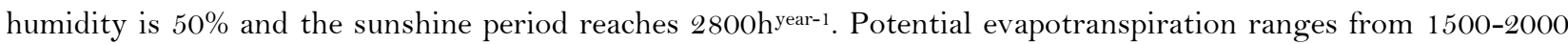
mmear-1 [3] and this range of ETP is relatively stable throughout the semiarid region [4].

In relation to geology, Jacomine [5] divided the region into three areas according to the nature of the originating material: areas of the lens, areas of the lens covered by more or less sandy materials, and sedimentary areas. Four orders of soil (Latosols, 19\%, Lithosolic, 19\%, Argissolos, 15\% and Luvisols, 13\%), out of a total of fifteen, occupy $66 \%$ of the area under caatinga, although they are spatially fractioned. More detailed descriptions of various aspects of the biome and its area of coverage were published by Sampaio, et al. [6]; Salcedo and Menezes [7]. The relief of the semi-arid region is very variable, which contributes to the large number of large landscape units. The average altitude is between 400 and $500 \mathrm{~m}$, but can reach $1000 \mathrm{~m}$. Around $37 \%$ of the area is of slopes with 4 to $12 \%$ of slope and $20 \%$ of slopes have a slope of more than $12 \%$, which determines a marked presence of erosive processes in the anthropic areas [8]. The variety of landscapes and environments must be highlighted as one of the most outstanding features of the region. The caatinga vegetation is distributed in 17 large landscape units, in turn subdivided into 105 geoenvironmental units [9] of a total of 172 in the whole Northeast [10]. The current situation is of deforestation of around $45 \%$ of the biome, the rest being in several successional stages, the soils, in general, present with signs of degradation due to erosive processes, compaction and loss of fertility due to anthropogenic action. As a result, several desertification nuclei have been identified in the region [11].

The change in soil use, converting natural ecosystems into agricultural systems, usually promotes the reduction of Soil Organic Matter (SOM) contents due to the alteration of the biogeochemical cycles [12]. For Schumacher, et al. [13] litter production and the return of nutrients to forest ecosystems are the most important route of the biogeochemical cycle (nutrient flow in the soil-plant-soil system). In addition to the effects on productive properties, the change in land use intensifies the emission of greenhouse gases, mainly $\mathrm{CO}_{2}$. The velocity of $\mathrm{CO}_{2}$ production has been used to better understand the functions of the decomposing population and the relationship with the environmental conditions [14, 15]. In this sense, there is a growing demand for knowledge of the $\mathrm{CO}_{2}$ flows involved, and the information in this regard in the semi-arid region is very scarce [16]. Physical attributes such as soil aggregation can be directly altered by their management or indirectly by biotic and abiotic factors that affect their stability [17] some groups of microorganisms are related to the soil aggregation process, Peng, et al. [18]. In the present study, it was found that the presence of glomalin was associated with a high degree of resistance to heat, insolubility and hydrophobicity. The presence of glomalin in soils is mainly due to its association with carbon, contributing to the increase of its soil reservoir [19].

\section{CHARACTERISTICS OF THE CAATINGA BIOME}

The Caatinga, the only semi-arid ecoregion in the world, is probably the Brazilian biome most threatened and transformed by human action [20]. It occupies a significant portion of the national territory. The region of semiarid 
climate mostly presents the shallow and stony soil, although relatively fertile and with smooth undulating relief. The aggressive aspect of the vegetation contrasts with the diversified coloring of the flowers in the rainy season. The temperature is between 24 and $26^{\circ} \mathrm{C}$ and varies little during the year. The current situation is of deforestation of around $45 \%$ of the biome, the rest being in several successional stages, the soils, in general, present with signs of degradation due to erosive processes, compaction and loss of fertility. As a result, several desertification nuclei have been identified in the region [11]. The change in soil use, converting natural ecosystems into agricultural systems, usually promotes the reduction of Soil Organic Matter (MOS) contents, due to the alteration of the biogeochemical cycles [12].

\subsection{Climate}

The Aw'i climate, according to the Koppen climate classification, is considered dry sub-humid. The rainy season is situated between the months of February to July and rains annually, about $800 \mathrm{~mm}$ (1974-2004). The average annual maximum temperature is $26{ }^{\circ} \mathrm{C}$ and the minimum temperature is $24{ }^{\circ} \mathrm{C}$, varying little over the year. Figure 1 shows the rainfall data from October 2017 to October 2018 at an experimental station in the Paraibana caatinga área, precipitation (quantity and intensity) was monitored by a meteorological station (model $\mathrm{HOBO} \mathbb{B}$ U30/NRC of Onset, Massachusetts, USA) installed in the area of the transect.

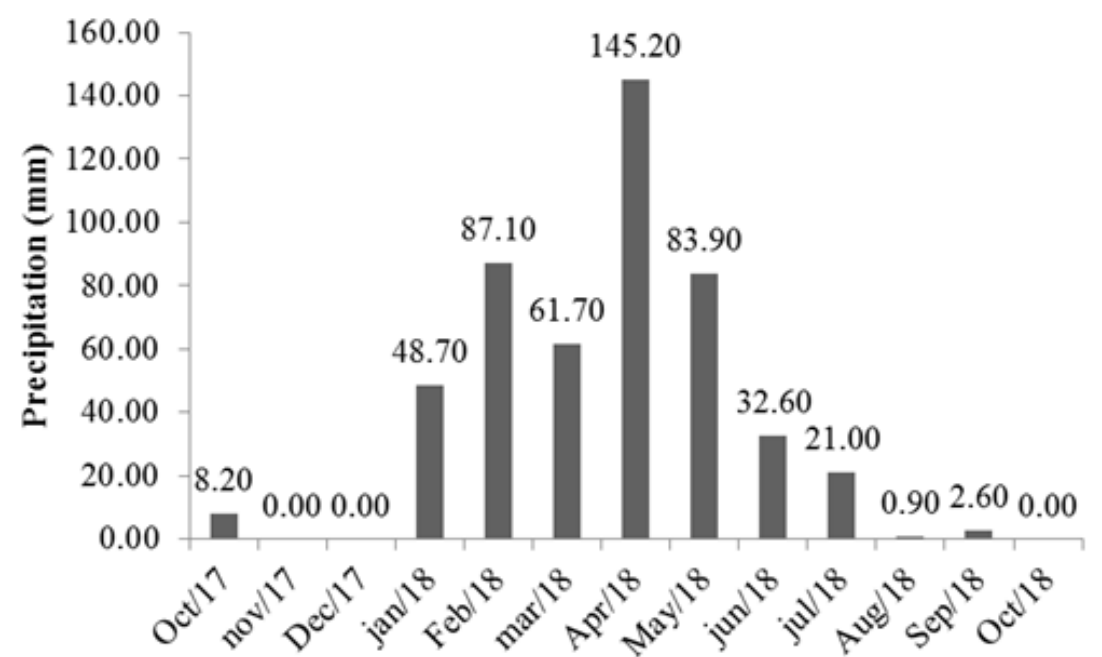

Figure-1. Monthly precipitation for 1 year in Caatinga area in natural regeneration stage. Source: Da Costa, et al. [21].

\subsection{Soils of the Semi-Arid Region}

Four orders of soil (Latosols, 19\%, Lithosolic, 19\%, Argissolos, 15\% and Luvisols, 13\%), out of a total of fifteen, occupy $66 \%$ of the area under caatinga, although they are spatially fractioned. More detailed descriptions of various aspects of the biome and its area of coverage were published by Salcedo and Sampaio [16]; Sampaio, et al. [6]; Salcedo and Menezes [7]. The Neosols, a class that predominates in the semi-arid region, are potentially limited soils because they are shallow and commonly stony and rocky. They present varying fertility, and erosion soil loss is naturally very high, being aggravated when the original vegetation is removed and soil deterioration [22].

Soil degradation can occur due to loss of chemical quality characterized by the decrease of the original organic matter contents and important mineral elements, to values below those considered critical for agricultural productivity [23]. The loss of physical quality may result from soil disintegration, surface compaction and subsurface compaction processes [24] one of the factors that leads to this degradation is the misuse of these lands, which suffer direct effect of the action anthropic [21] in a research developed in the area of littoral Neolithic under caatinga vegetation in a state of regeneration at 30 years, found values that show that the soil of this area has been 
recovering its chemical and physical characteristics so that it can offer adequate conditions so that the vegetation can develop in this environment more efficiently, increasing its resilience [25].

\subsection{Production of litter}

According to Soares, et al. [26] most of the nutrients absorbed by plants return to the soil by the fall of senescent components of the aerial part and their subsequent decomposition. In forest ecosystems, mineral and organic reserves accumulate in plant and animal biomass, litter and soil [27] and anthropogenic interventions compromise the inflow and outflow of nutrients into the system. These organic fragments, when falling on the ground, form a layer called litter, which includes leaves, stems, fruits, flowers.

The litter is particularly important because it acts on the soil surface as an input and output system, receiving entrances through vegetation and, in turn, decomposing and supplying the soil and roots with nutrients and organic matter, being essential in the restoration of fertility in areas at the beginning of ecological succession [28]. The litter deposition patterns introduce temporal and spatial heterogeneity in the environment, which can affect the structure and dynamics of the plant community [29, 30]. The contribution of litter is a dynamic process of evaluation of aerial biomass in forests, and the production of leaf material represents an important flow of nutrient transfer to the forest soil [31]. The amount of organic material deposited on the soil over a year is mainly related to the climatic conditions and the type of vegetation [32]. Given this context, we can see the multiple positive functions that the litter provides for the ecological environment and, there is a dynamic in the biogeochemical cycling for the different forest ecosystems, that provides improvement in the chemical and physical attributes of the soil, however, it is believed that, among the different forest typologies, there are intrinsic abiotic factors influencing the cycling process, configured through different behaviors of vegetable waste and nutrients.

\subsection{Layer Decomposition and Nutrient Cycling}

The decomposition of the organic residues that form the litter is the main process of nutrient cycling in a forest ecosystem [33]. The study of mineral nutrient cycling via litter is of fundamental importance for the knowledge of the structure and functioning of forest ecosystems. [34] describes that the quality of organic matter is of fundamental importance for most of the functional processes that occur in the soil of forest ecosystems. The nutrient cycling in forest ecosystems, planted or natural, has been extensively studied in order to obtain a better knowledge of the nutrient dynamics in these environments, not only for understanding the functioning of ecosystems, but also seeking information for the establishment of practices of forest management for the recovery of degraded areas and to promote the preservation of vegetation. The litter deposition process, including the annual rates of fall of the deciduous material, the decomposition process of this material and the nutrient dynamics in the Caatinga area, should be widely studied, especially in semi-arid conditions, where there is a high occurrence of soils with low levels of nutrients. Thus, in order to better understand the flow of input and output of nutrients in the plant-soil system in the semi-arid region of Paraiba, so that conservation mitigation measures can be proposed.

\subsection{Efflux of $\mathrm{CO}_{2}$}

In addition to the effects on productive properties, the change in land use intensifies the emission of greenhouse gases, mainly $\mathrm{CO}_{2}$. The velocity of $\mathrm{CO}_{2}$ production has been used to better understand the functions of the decomposing population and the relationship with the environmental conditions $[14,15]$. In this sense, there is a growing demand for knowledge of the $\mathrm{CO}_{2}$ flows involved, and the information in this regard in the semi-arid region is very scarce [16]. $\mathrm{CO}_{2}$ is today the main greenhouse gas and the constant increase of its concentration in the atmosphere has been blamed as the main vector of climate change attributed to global warming [35]. Emissions from the soil surface are caused by root and mycorrhizal respiration (autotrophic respiration) and organic matter decomposition (heterotrophic respiration) [36]. These emissions are linked to climate change, since both rainfall 
and temperature exert a strong control over biological activity. Other soil physical properties, such as aeration, also influence $\mathrm{CO}_{2}$ flow [37]. Soil respiration is the main pathway in which $\mathrm{C}$ is released from the soil [38]. Soil $\mathrm{CO}_{2}$ flow measurement can represent $60-90 \%$ of total ecosystem respiration, thus being the most widely used method to estimate soil respiration rate in situ [39]. Therefore, the understanding and quantification of the $\mathrm{CO}_{2}$ flux of the soil is of great importance when it comes to studies of ecosystems, since it has a direct relation with the dynamics and global balance of $\mathrm{C}$. The $\mathrm{CO}_{2}$ flux results from the biological activity in the soil and therefore has a strong spatial and temporal dependence on soil moisture and temperature [40, 41].

There is a lack of in-situ data for the semi-arid region [16]. A first attempt to quantify the emission of in situ $\mathrm{CO}_{2}$ in a hypoxerophilic caatinga area was performed by Souza [42] using the static chamber with alkali trap technique to capture the emitted $\mathrm{CO}_{2}$. This technique was recently evaluated by Araujo, et al. [43] and Ivo and Salcedo [44] who quantified the $\mathrm{CO}_{2}$ flow in the Cariri Paraibano area.

\subsection{Production of Glomalin and Soil Aggregation}

Soil aggregation can also be altered directly by its management or indirectly by biotic and abiotic factors that affect its stability [17] and is therefore considered a physical indicator of soil quality. The aggregates make up the soil structure and are important for the maintenance of porosity and consequently aeration, for plant and microbial growth, water infiltration and control of erosive processes [45]. Some groups of microorganisms are related to the processes of aggregation of soils. Among these microbial groups are arbuscular mycorrhizal fungi (AMF). Its importance is due not only to the mechanical effect of hyphae but also to the production of a glycoprotein of a hydrophobic nature called glomalin. In the present study, it was found that the presence of fungal hyphae was associated with the presence of the fungal hyphae. The nature of glomalin (heat resistance, insolubility and hydrophobicity) guarantees its cementing function, being usually used in aggregation studies due to the strong correlation with the stability of aggregates [18]. The presence of glomalin in soils is mainly due to its association with carbon, contributing to the increase of its soil reservoir [19]. Usually, this protein is separated into two fractions: fraction 1, or easily extractable; and fraction 2, or total (extracted with difficulty) [46]. The first fraction would have reference to the recently produced glomalina by the fungi, while the second would be the result of the accumulation of the first one over time, more recalcitrant, and would suffer actions of weathering [46-48].

The quantification of glomalin can be a good indicator of changes caused by land use and, therefore, can become a good indicator of its recovery because it is correlated with important soil attributes [49-51].

\section{CONCLUSIONS}

Studies that make possible the understanding of the processes of nutrient cycling and maintenance of soil fertility in the caatinga biome are necessary to assist in the proposition of possible management forms, in view of the sustainability of this ecosystem, providing data in an area of scientific knowledge that is directly related to the issue of climate change, quantifying, in-situ, the flow of $\mathrm{CO}_{2}$ from the soil, a gas relevant to the greenhouse effect.

The relevance of glomalin since it can be a good indicator of changes caused by land use and therefore, can be a good indicator of its recovery because it is correlated with important attributes of the soil. The linkage of these data to rainfall will allow the development of models related to both variables, which are not currently available for the tropical semiarid region.

Funding: This study received no specific financial support.

Competing Interests: The authors declare that they have no competing interests.

Acknowledgement: All authors contributed equally to the conception and design of the study.

\section{REFERENCES}

[1] MMA, "Caatinga. Retrieved from http://www.mma.gov.br/biomas/caatinga. [Accessed November 10, 2014 ]," 2014. 
[2] U. P. D. Albuquerque and L. D. H. C. Andrade, "Traditional botanical knowledge and conservation in an area of caatinga in Pernambuco state, Northeast Brazil," Brazilian Botanical Act, vol. 16, pp. 273-285, 2002.

E. V. S. B. Sampaio, Overview of the Brazilian Caatinga. In: S.H. Bullock; H. Mooney, E. Medina. Seasonally dry tropical forests. Cambridge: Cambridge University Press, 1995.

R. S. C. Menezes and E. V. S. B. Sampaio, Sustainable agriculture in the northeastern semi-arid region. In: T.S. Oliveira, R.E.

Romero, R.N. Assis Júnior, J.R.C.S. Silva. Agriculture, sustainability and the semi-arid. Fortaleza-CE: Brazilian Society of Soil Science / Federal University of Ceará, 2000.

[5] P. K. T. Jacomine, Soils under caatinga: Characteristics and agricultural use. In: Alvarez V., V.H. Fontes. The soil in the great morphoclimatic domains of Brazil and sustainable development. Viçosa: MG, SBCS / UFV / DPS, 1996.

[6] E. V. S. B. Sampaio, M. d. S. B. de Araújo, I. H. Salcedo, and R. S. C. Menezes, Sustainable agriculture in the Northeastern Semi-arid, 1st ed. vol. 152. Recife: University Publishing House of UFPE, 2009.

[7] I. H. Salcedo and R. S. C. Menezes, Agroecosystem functioning and management in semiarid Northeastern Brazil. In: Tiessen, H., J.W.B. Stewart. (Org.): Applying Ecological Knowledge to Landuse Decisions: InterAmerican Agency for Global Change Research / SCOPE, 2009.

[8] J. R. C. Silva, Erosion and soil productivity in the semiarid region. In: T.S. Oliveira, R.N. Assis Júnior, R.E. Romero, J.R.C. Silva, (Eds.), Agriculture, sustainability and the semi-arid. Fortaleza: Federal University of Ceará - Brazilian Soil Science Society, 2000 .

[9] M. J. N. Rodal and E. V. S. B. Sampaio, The vegetation of the caatinga biome. In: E.V.S.B. Sampaio, A.M. Giulieti, J. Virginio, C.F.L. Gamarra Rojas. Vegetation and flora of the Caatinga. Recife: APNE, 2002.

[10] F. B. R. Silva, G. R. Riche, J. P. Tonneau, N. C. Souza Neto, L. T. d. L. Brito, R. C. Correia, A. C. Cavalcanti, F. H. Silva, B. B. Silva, and P. J. C. de Araujo Filho, Leite Northeast agroecological zoning: Diagnosis of the natural and agrossocioeconomico framework. Petrolina: EMBRAPA-CPATSA, 1993.

[11] A. M. Perez-Marin, A. M. B. Cavalcante, S. S. Medeiros, L. B. M. Tinôco, and I. H. Salcedo, "Desertification nuclei of Brazilian semiarid: Natural or anthropic occurrence?," Strategic Partnerships, vol. 17, pp. 87-106, 2012.

[12] V. Da Silva Fraga and I. H. Salcedo, "Declines of organic nutrient pools in tropical semi-arid soils under subsistence farming," Soil Science Society of America Journal, vol. 68, pp. 215-224, 2004.Available at: https://doi.org/10.2136/sssaj2004.2150.

[13] M. V. Schumacher, E. J. Brun, J. I. Hernandes, and F. G. König, "Production of litter in a forest of Araucaria angustifolia (Bertol.)," Kuntze in the Municipality of Pinhal Grande, vol. 28, pp. 29-37, 2004.

[14] S. L. d. Assis Júnior, J. C. Zanuncio, M. C. M. Kasuya, L. Couto, and R. C. Melido, "Soil microbial activity in agroforest, monocultures, natural forest and deforested area systems," Tree Magazine, vol. 27, pp. 35-41, 2003.

[15] P. C. Souto, "Study of the dynamics of manure decomposition in the recovery of degraded soils in the semi-arid region of Paraiba," Dissertation Master in Soil and Water Management - Center of Agrarian Sciences, Federal University of Paraíba, Areia, 2002.

[16] I. H. Salcedo and E. V. S. B. Sampaio, Soil organic matter in the Caatinga biome. In: Basics of soil organic matter: Tropical and subtropical ecosystems. G.A. Santos,; L.P. Canellas, F.A.O. Camargo. Porto Alegre: Metropolis, 2008.

[17] E. K. Barto, F. Alt, Y. Oelmann, W. Wilcke, and M. C. Rillig, "Contributions of biotic and abiotic factors to soil aggregation across a land use gradient," Soil Biology and Biochemistry, vol. 42, pp. 2316-2324, 2010.Available at: https://doi.org/10.1016/j.soilbio.2010.09.008.

[18] S. Peng, T. Guo, and G. Liu, "The effects of arbuscular mycorrhizal hyphal networks on soil aggregations of purple soil in Southwest China," Soil Biology and Biochemistry, vol. 57, pp. 411-417, 2013.Available at: https://doi.org/10.1016/j.soilbio.2012.10.026.

[19] J. D. Driver, W. E. Holben, and M. C. Rillig, "Characterization of glomalin as a hyphal wall component of arbuscular mycorrhizal fungi," Soil Biology and Biochemistry, vol. 37, pp. 101-106, 2005.Available at: https://doi.org/10.1016/j.soilbio.2004.06.011. 
[20] C. H. M. Casteleti, A. M. M. Santos, M. Tabarelli, and J. M. C. Silva, How much remains of the Caatinga? A preliminary estimate. In: Leal, L.R.; M. Tabarelli, J.M.C. Silva. Ecology and conservation of the Caatinga. Recife: Publisher of UFPE, 2003.

[21] C. R. G. Da Costa, V. Da Silva Fraga, G. R. Lambais, K. O. Soares, S. R. P. Suddarth, and S. De Sousa Medeiros, "Chemical and physical quality of the entisol in a natural regeneration area in the semiarid region of paraiba," Journal of Experimental Agriculture International, pp. 1-7, 2019.Available at: https://doi.org/10.9734/jeai/2019/v35i230202.

[22] N. F. C. Corado, "Spatial variability of aggregates and total organic carbon in Eutrophic Littoral Neosol in the municipality of Gilbués, PI," Journal of Agricultural Sciences, vol. 58, pp. 75-83, 2015.

[23] A. F. Queiroz, "Characterization and classification of soils of the municipality of Casa Nova-BA for use, management and conservation purposes," Dissertation (Master's Degree in Soil Science) - Federal Rural Semiarid University (UFERSA), Mossoró-RN, 2013.

[24] A. Richart, J. Tavares Filho, O. R. Brito, R. F. Llanillo, and R. Ferreira, "Soil compacting: Causes and effects," Seminar: Agricultural Sciences, vol. 26, pp. $321-344,2005$.

[25] C. R. G. Da Costa, M. G. Da Silva, R. S. M. da Cunha, M. M. de Sousa, A. C. M. Linhares, S. de Sousa Silva, A. de Lima Marques, D. C. de Moura, R. F. Batista, and J. A. M. de Lima, "Richness and diversity of the edaphic Macrofauna in a Brazilian seasonally dry tropical forest," Journal of Experimental Agriculture International, vol. 42, pp. 80-85, 2020.Available at: https://doi.org/10.9734/jeai/2020/v42i930589.

[26] I. Soares, J. A. Queiroz, V. H. Oliveira, L. A. Crisóstomo, and T. S. Oliveira, "Production of litter and nutrient cycling in the precocious dwarf Cajueiro crop," Version Price, vol. 32, pp. 173-181, 2008.

[27] M. G. Pereira, T. Menezes, and N. Shultz, "Contribution and decomposition of litter in the Atlantic forest, Marambaia Island, Mangaratiba, RJ," Forest Science, vol. 18, pp. 443-454, 2008.

[28] J. Ewel, "Litterfall and leaf decomposition in a tropical forest succession in eastern Guatemala," Journal of Ecology, vol. 64, pp. 293-308, 1976.Available at: https://doi.org/10.2307/2258696.

[29] J. M. Facelli and S. T. Pickett, "Plant litter: Its dynamics and effects on plant community structure," The Botanical Review, vol. 57, pp. 1-32, 1991.Available at: https://doi.org/10.1007/bfo2858763.

[30] J. Molofsky and C. K. Augspurger, "The effect of leaf litter on early seedling establishment in a tropical forest," Ecology, vol. 73, pp. 68-77, 1992.Available at: https://doi.org/10.2307/1938721.

[31] P. Jha and K. P. Mohapatra, "Leaf litterfall, fine root production and turnover in four major tree species of the semiarid region of India," Plant and Soil, vol. 326, pp. 481-491, 2010.Available at: https://doi.org/10.1007/s11104-0090027-9.

[32] F. L. O. Corrêa, J. D. Ramos, A. C. Gama-Rodrigues, and M. W. Muller, "Production of litter in a multi-stratified agroforestry system in the State of Rondônia, Brazil," Agrotechnical Science, vol. 30, pp. 1099-1 105, 2006.

[33] F. Montagnini and C. F. Jordan, Nutrient recycling. In: M.R. Guariguata, G.H. Kattan (Eds.), Ecology and conservation of neotropical forests. Carthage: Ediciones LUR, 2002.

[34] I. S. Regina, "Litter fall, decomposition and nutrient release in three semi-arid forests of the Duero Basin, Spain," Forestry, vol. 74, pp. 347-358, 2001.Available at: https://doi.org/10.1093/forestry/74.4.347.

[35] R. Lal, "Soil carbon sequestration to mitigate climate change," Geoderma, vol. 123, pp. 1-22, 2004.Available at: https://doi.org/10.1016/j.geoderma.2004.01.032.

[36] Y. Luo and X. Zhou, Soil respiration and the environment. San Diego: Elsevier, 2006.

[37] K. A. Smith, T. Ball, F. Conen, K. E. Dobbie, J. Massheder, and A. King, "Exchange of greenhouse gases between soil and atmosphere: Interactions of soil physical factors and biological processes," European Journal of Soil Science, vol. 54, pp. 779-791, 2003.

[38] E. Sotta, E. Veldkamp, B. Guimaraes, R. Paixao, M. Ruivo, and S. Almeida, "Landscape and climatic controls on spatial and temporal variation in soil $\mathrm{CO} 2$ efflux in an Eastern Amazonian Rainforest, Caxiuana, Brazil," Forest Ecology and Management, vol. 237, pp. 57-64, 2006.Available at: https://doi.org/10.1016/j.foreco.2006.09.027. 
[39] Y. Kuzyakov, "Sources of $\mathrm{CO} 2$ efflux from soil and review of partitioning methods," Soil Biology and Biochemistry, vol. 38, pp. 425-448, 2006.Available at: https://doi.org/10.1016/j.soilbio.2005.08.020.

[40] S. Kang, S. Doh, D. Lee, D. Lee, V. L. Jin, and J. S. Kimball, "Topographic and climatic controls on soil respiration in six temperate mixed-hardwood forest slopes, Korea," Global Change Biology, vol. 9, pp. 1427-1437, 2003.Available at: https://doi.org/10.1046/j.1365-2486.2003.00668.x.

[41] D. Epron, Y. Nouvellon, O. Roupsard, W. Mouvondy, A. Mabiala, L. Saint-André, R. Joffre, C. Jourdan, J.-M. Bonnefond, and P. Berbigier, "Spatial and temporal variations of soil respiration in a Eucalyptus plantation in Congo," Forest Ecology and Management, vol. 202, pp. 149-160, 2004.Available at: https://doi.org/10.1016/j.foreco.2004.07.019.

[42] F. J. Souza, "C-CO2 flow of a eutrophic regolithic Neosol under caatinga vegetation in Caruaru-PE," Dissertation Master's Degree in Agronomy (Soil Science) -Universidade Federal de Pernambuco, Recife, PE, 2000.

[43] K. D. Araujo, A. P. De Andrade, P. R. De Oliveira Rosa, R. d. L. A. Bruno, and V. Da Silva Fraga, "Evaluation of microbial activity based on the production of $\mathrm{C}-\mathrm{CO} 2$ in a caatinga area in Cariri Paraíba," Caatinga Magazine, vol. 21, pp. $221-230,2008$.

[44] W. M. P. d. M. Ivo and I. H. Salcedo, "Soil CO2 flux: A method comparison of closed static chambers in a sugarcane field," Brazilian Journal of Soil Science, vol. 36, pp. 421-426, 2012.Available at: https://doi.org/10.1590/s010006832012000200011 .

[45] R. S. Bastos, "Formation and stabilization of soil aggregates influenced by wetting cycles and drying after addition of organic compounds with different hydrophobic characteristics," Brazilian Journal of Soil Science, vol. 29, pp. 21-31, 2005.

[46] S. F. Wright and A. Upadhyaya, "Extraction of an abundant and unusual protein from soil and comparison with hyphal protein of arbuscular mycorrhizal fungi," Soil Science, vol. 161, pp. 575-586, 1996.Available at: https://doi.org/10.1097/00010694-199609000-00003.

[47] R. T. Koide and M. S. Peoples, "Behavior of Bradford-reactive substances is consistent with predictions for glomalin," Applied Soil Ecology, vol. 63, pp. 8-14, 2013.Available at: https://doi.org/10.1016/j.apsoil.2012.09.015.

[48] Q.-S. Wu, M.-Q. Cao, Y.-N. Zou, and X.-h. He, "Direct and indirect effects of glomalin, mycorrhizal hyphae and roots on aggregate stability in rhizosphere of trifoliate orange," Scientific Reports, vol. 4, pp. 1-8, 2014.

[49] M. C. Rillig, F. T. Maestre, and L. J. Lamit, "Microsite differences in fungal hyphal length, glomalin, and soil aggregate stability in semiarid Mediterranean steppes," Soil Biology and Biochemistry, vol. 35, pp. 1257-1260, 2003.Available at: https://doi.org/10.1016/s0038-0717(03)00185-8.

[50] P. V. Truber, "Soil aggregation and occurrence of arbuscular mycorrhizal fungi in crop rotation systems," Dissertation. São Paulo State University, Faculty of Agrarian and Veterinary Sciences, Jaboticabal, 2013.

[51] M. C. Rillig, C. A. Aguilar-Trigueros, J. Bergmann, E. Verbruggen, S. D. Veresoglou, and A. Lehmann, "Plant root and mycorrhizal fungal traits for understanding soil aggregation," New Phytologist, vol. 205, pp. 1385-1388, 2015.Available at: https://doi.org/10.1111/nph.13045

Views and opinions expressed in this article are the views and opinions of the author(s), Journal of Forests shall not be responsible or answerable for any loss, damage or liability etc. caused in relation to/arising out of the use of the content. 